Article

\title{
Reimagining the Medieval: The Utility of Ethnonational Symbols for Reactionary Transnational Social Movements
}

\author{
Matthew Godwin ${ }^{1, *}$ and Elisabeth Trischler ${ }^{2}$ \\ ${ }^{1}$ Tony Blair Institute for Global Change, UK; E-Mail: m.godwin@institute.global \\ ${ }^{2}$ Institute for Medieval Studies, University of Leeds, UK; E-Mail: hy14ekt@leeds.ac.uk \\ * Corresponding author
}

Submitted: 30 December 2020 | Accepted: 3 June 2021 | Published: 27 August 2021

\begin{abstract}
Scholars have explored the rise of far-right reactionary political parties in Europe over the last decade. However, social movements reflecting similar political orientations have rarely been conceptualized as "reactionary." To better understand the political orientations of reactionary transnational social movements such as the Identitarians and the Defence Leagues, we explore how and why ethnonational symbols derived from the medieval period are utilized by adherents. This interdisciplinary investigation argues that, through processes of mediated political medievalism, ethnonational symbols are used as strategic framing devices to reimagine an idealized "golden age" of distinct European nations, to assign blame for the erosion of ethnonational identity through multiculturalism, immigration and "Islamization," to establish an intergenerational struggle against the supposed incursion of Islam in Europe, and to proscribe and justify the use of violence as a means of re-establishing the primacy of European nations.
\end{abstract}

\section{Keywords}

crusades; Defence League; ethnonational symbols; Identitarians; medievalism; reactionary movements

Issue

This article is part of the issue "Reactionary Politics and Resentful Affect in Populist Times" edited by Tereza Capelos (University of Birmingham, UK), Stavroula Chrona (King's College London, UK), Mikko Salmela (University of Helsinki, Finland / University of Copenhagen, Denmark), and Cristiano Bee (Oxford Brookes University, UK).

(C) 2021 by the authors; licensee Cogitatio (Lisbon, Portugal). This article is licensed under a Creative Commons Attribution 4.0 International License (CC BY).

\section{Introduction}

The rise of reactionary politics in European countries in recent decades has led scholars to consider the origins, orientations, and success of nationalistic, far-right, populist political parties (Grindheim, 2019; Rooduijn, 2015; Wodak, 2015). In parallel, scholars have also charted the mobilization of non-party political far-right social movements such as the English Defence League in Great Britain and Génération Identitaire in France (Busher, 2016; Eatwell \& Goodwin, 2010; Guenther et al., 2020; Zúquete, 2018). A range of grievances common to both far-right parties and social movements include the loss of national attachments and ethnocultures through processes of multiculturalism, the threat to majority populations by immigration, and a perceived threat to
"Indigenous" nations by Islam (Bernsand, 2013; Capelos \& Katsanidou, 2018; Kassimeris \& Jackson, 2015).

In addition to these common grievances, many reactionary social movements in Europe evince the use of images and narratives drawn from the medieval period (Koch, 2017). At the heart of this inquiry is the question: What does the appropriation of themes from the medieval past tell us about the grievances, objectives, and strategies of reactionary social movements? By conceptualizing far-right, transnational social movements as "reactionary" movements, we consider their use of "radical nostalgia" to construct ethnonational symbols as strategic framing devices. Focused on the appropriation of symbols derived from the medieval period with an emphasis on the crusades, we explore the Identitarians and the Defence Leagues in Europe. 
The former announced its existence in France in 2012 as Génération Identitaire through a protest located at a site associated with the 732 CE Battle of Tours (Simpson \& Druxes, 2015, p. 177). Similarly, the inaugural appearance of the English Defence League in England in 2009 on St. George's Day was organized in part by an activist dubbing himself Paul "The Lionheart" Ray (Busher, 2016, p. 4). From the outset, both transnational social movements have strategically framed reactionary political orientations through utilizing ethnonational symbols. Originating in a radically nostalgic interpretation of the medieval period, particularly those associated with the crusades, the Identitarians and Defence Leagues reimagine a lost "golden age" of both ethnonational distinctiveness as well as European mobilization against an external "other." Some examples of these themes are depicted below, such as a crusader knight in prayer (Figure 2) and a mythologized crusading knight chasing away an observably Muslim mother (Figure 3).

This interdisciplinary inquiry unfolds in three phases. The first section reviews the conceptual and empirical literature on the Identitarians and Defence Leagues. While accepting the conceptual framework of earlier scholarship, we argue firstly that these social movements should also be considered "reactionary," especially through their radically nostalgic reimagining of the medieval period. Secondly, despite their ethnic nativism, the Identitarians and Defence Leagues should also be considered "transnational" social movements. This section then presents the analytical framework, arguing that an ethnosymbolic approach best suits consideration of how these movements operationalize "medievalism" to construct ethnonational symbols derived from a radically nostalgic reimagining of the medieval period. It then adopts a strategic framing lens to explore the utility of ethnonational symbols, with a focus on problem definition, causal attribution, moral evaluation, and treatment recommendations.

The second section presents a range of images and narratives drawn from public content of the Identitarians and the Defence Leagues, in which they utilize appropriated symbols from the medieval period online and at demonstrations. The historical context from which these symbols are derived is provided with a focus on medieval encounters in which a predominately Christian Europe is engaged in single or prolonged confrontation with Islamic powers.

The final section discusses the utility of ethnonational symbols derived from the medieval period for reactionary social movements: Firstly, ethnonational symbols frame core, interrelated problems for adherents, including the perceived loss of "native" European nations and cultures, attributed casually to the European Union's support for multicultural civic nationalism; concomitant increases in non-European immigration and in particular the immigration of Muslims. Secondly, ethnonational symbols create a moral framework of "us vs. them," civilizational struggle against anti-nativist and non-European forces, illustrating the existential consequences of this struggle and establishing a sense of urgency. Finally, ethnonational symbols have prescriptive utility by surreptitiously conveying the need to expel immigrants, including through the use of violence.

\section{Reimagining the Medieval: Reactionary Transnational Social Movements and Medievalism}

This section conceptualizes and explores the Identitarians and the Defence Leagues, arguing that they are reactionary, transnational social movements. Secondly, we present a theoretical framework grounded in ethnosymbolism as a means of explaining the utility of ethnonational symbols for reactionary social movements, medievalism as the process by which symbols are constructed, and how they are ultimately employed as strategic framing devices.

\subsection{Defining the Identitarians and Defence Leagues}

Scholars have extensively explored a range of domestic and transnational far-right social movements in Europe, such as CasaPound, in Italy, Pegida, which was founded in Germany, and Soldiers of Odin, which emerged in Scandinavia (Caiani, 2019; Castelli Gattinara \& Froio, 2014). In addition to transnational cooperation, many of these movements exhibit reactionary and radically nostalgic orientations. However, this inquiry focuses its attention on the Identarian and Defence League far-right social movements as a consequence of their ubiquitous and foundational use of ethnonational symbolism derived from the medieval period.

The Identitarian movement began in France in the 1960 s as a reaction against the intellectual liberal-left, describing its orientation as the "new right." It has predominated on continental Europe and continues to be driven principally by a reaction to liberal internationalism, global homogenization, and a vehement opposition to immigration (Zúquete, 2018, p. 7). Strongest in Italy and France, groups such as CasaPound in Italy and Génération Identitaire in France oppose the liberal-left establishment and neo-conservatives, declaring themselves the "true right" mobilized against borderless capitalism. The Identitarians defend the "right to difference" and believe that sentiments of belonging to humanity are mediated through culture; as a consequence, they are determined to revitalize ethnonational, primordial traditions. The modern incarnation of the Identitarian movement was founded as Génération Identitaire in France in 2012, surfacing as a youth division of the Bloc Identitaire (Richards, 2019).

Since the early 2010s, the Identitarians began to coordinate transnationally to establish more permanent networks and to share tactics. In Fulda, in 2014, a gathering of adherents committed to creating local teams and to coordinate specific regions (Simpson \& Druxes, 2015, p. 184). Across Europe, tens of thousands are believed 
to belong to Identitarian chapters in countries such as Germany, Austria, Belgium, and Italy. Local Identitarian movements are oriented toward the ethnonational identity of their territory, such as CasaPound in Italy and the Flemish Schild \& Vrienden (Maly, 2018). Identitarians across Europe meet once annually to learn combat techniques and plan common campaigns. They share similar signs and symbols, including using the handshake of Roman legionnaires (Durie, 2019). In recent years, the Identitarians have coordinated transnational campaigns, including the 2017 Defend Europe boats mission in the Mediterranean and the 2016 Summer of Resistance demonstrations in Paris, Vienna, and Berlin (Nissen, 2020).

The English Defence League was formed in Luton in 2009 and has mobilized members principally around contempt for Islam. It emerged from anti-Jihad movements and from football hooliganism, and its first demonstration was held in response to protests orchestrated against the return of British troops from the Middle East (Busher, 2016, p. 5; Jackson \& Feldman, 2011, p. 8). Despite having a stronger inclination toward violence as a mobilizing force than the Identitarians, Defence Leagues adherents similarly assert their disavowal of biological racism in favor of an emphasis on protecting culture, an antipathy to "liberal elites," and a deeply held paranoia of an imperialist Islam which they believe is threatening to replace the majority population of European states (Meleagrou-Hitchens \& Brun, 2013; Morrow \& Meadowcroft, 2019). Like the Identitarians, the Defence Leagues also subscribe to the view that these forces will result in an existential civilizational conflict.

The transnational Defence League network (or European Defence League) emerged in the late 2000s/ early 2010s as an outgrowth of the creation of the English Defence League (Elliott, 2017, p. 157). Following a falsestart in Amsterdam in 2010, the Defence League was reconstituted at a counter-Jihad rally of Defence Leagues in Denmark, with representatives drawn from Defence Leagues in Denmark, Norway, Sweden, Finland, UK, Germany, Russia, and elsewhere (Hope Not Hate, n.d.). In addition to common objectives, Defence Leagues have established networks that share information and strategies. Like the Identitarians, they also share similar strategic frames including the adoption of ethnonational symbols appropriated from the medieval period.

The Identitarians and Defence Leagues have mobilized thousands across Europe in opposition to immigration and Islam and have been variously defined as far-right extremists, fascists, and radicals (Castelli Gattinara \& Pirro, 2019; Kassimeris \& Jackson, 2015; Mattheis \& Winter, 2019; Meleagrou-Hitchens \& Brun, 2013; Richards, 2019). The constituent national entities of the Identitarian movement and the Defence League have been described as "nativist," which Castelli Gattinara and Pirro (2019) term "a radical and exclusionary form of nationalism" (p. 1). Nativism describes the exclusionary "us vs. them" boundary created by these movements, emphasizing local attachments and a paramount identification with nations composed of narratives of linguistic and cultural inheritance (Olsson, 2009, p. 113). The Identitarians and Defence Leagues espouse a kind of "cultural nationalism" where they advance that experience is mediated principally through culture, that culture emerges from the traditions of nations, and that the loss of culture erodes their ethnonationalist view of identity (Meleagrou-Hitchens \& Brun, 2013, p. 25; Muis \& Immerzeel, 2017). Despite efforts to avoid being described as racist, this orientation is a form of "ethnic" nationalism rather than "civic" nationalism, whereby adherents emphasize the unique origins, history, and cultures of nations, and employ symbolic mythmaking to develop exclusive, ethnonationalist identities (Kaufmann, 2019). For these groups, nativist ethnic nationalism creates in-group and out-group dichotomies bounded by identity, especially ethnic, cultural, and ancestral markers (Conversi, 2009, p. 82; Ford, 2010, p. 148; Mudde, 2007).

These nativist ethnonationalist orientations have given rise to a number of political objectives. Firstly, their nativist orientations oppose civic nationalism and the EU's effort to create a multicultural pan-European identity referred to as "supranationalism" (Karolewski, 2009, p. 66; Kuzio, 2009, p. 14; Zúquete, 2015). Reactionary far-right social movements consider this liberal project a "back door" to mass immigration and the consequent destruction of European nations (MeleagrouHitchens \& Brun, 2013, p. 42). Secondly, despite purporting to espouse a non-hierarchical nationalism, they are aggressively anti-immigration. The Identitarians and Defence Leagues adhere to a paranoia that the "Indigenous" population of Europe is being superseded in a "great replacement" whereby non-majority Europeans, particularly Muslims, will become the demographic majority through both migration and higher birthrates (Meleagrou-Hitchens \& Brun, 2013, p. 49; Nissen, 2020; Pilkington, 2016, p. 135; Richards, 2019). In response, they advocate "remigration": the expulsion of all those not of European ethnicity from Europe (Ebner, 2019). Finally, bound up in their hostility to immigration is Islamophobia and their opposition to the "Islamification" of Europe (see Kaya, 2021, for more on Islamophobia and right-wing nativism). Paranoia against Islam is infused with baseless accusations, such as a predilection for pedophilia and a conspiratorial belief that a monolithic imperialist Islam is seeking to conquer the West (Jackson \& Feldman, 2011, p. 9; Koch, 2017; Nissen, 2020; Pilkington, 2016, p. 135).

These political orientations are manifested in direct action campaigns such as those against the building of Mosques, the immigration of refugees, and the provision of Halal meats (Caiani, 2019; Meleagrou-Hitchens \& Brun, 2013, pp. 38, 59). However, far-right social movement mobilization of the Identitarians and Defence Leagues are also concerned with more paradigmatic change for which ethnonational symbolism is particularly 
consequential. Firstly, the above grievances are elevated by adherents to a continent-wide, generational, civilizational struggle whereby "Europeans" are in an existential conflict with external, primarily Islamic forces (Caiani \& Weisskircher, 2019; Meleagrou-Hitchens \& Brun, 2013, p. 2; Nissen, 2020). As argued below, this "clash of civilizations" frame is encapsulated by the Identitarians and Defence Leagues through the use of ethnonational symbols drawn from the medieval period, particularly those from the crusades, when European powers fought extensively with Islamic forces. Secondly, an overarching belief amongst far-right social movement adherents is that distinct European nations existed in a mythologized "golden age," where they were territorially bounded and "pure" without dilution through significant interrelations with other nations (Nissen, 2020). Identitarian and Defence League adherents resent the emergence of multicultural societies which they argue have eroded national cultures and is abetted through parallel forces of immigration and Islamization. As a part of this "grand narrative," adherents furthermore idealize a return to a mythologized period when nations were not only distinct, but also united in their collective opposition to the supposed loss of their civilization. Mobilization around these themes can be conceptualized as a form of "radical nostalgia."

Radical nostalgia has been recently discussed by Kenny (2017) in the context of far-right populism in Europe, where adherents recollect past times or "enchanted places" and utilize a "selective deployment of the national past" (pp. 256-261). They cite Freeden to argue that radical nostalgists seek "to establish a kind of temporal sovereignty which is depicted as the source of an exclusive national-cultural tradition" (Freeden as cited in Kenny, 2017, p. 257). As argued below, the Identitarians and Defence Leagues are motivated by a desire to halt multiculturalism, immigration, and the presence of Islam in Europe with a view to returning to a radically nostalgic imagining of a mythologized past where European nations were distinct and "pure," but were nevertheless united in collective opposition to the incursion of external, primarily non-European, forces. Radical nostalgia aligns with the aforementioned perception that identity can only be maintained through cultural manifestations of a shared ethnic past and that it is this shared history that not only defines the nation, but excludes others from membership.

The above political orientations of the Identitarians and Defence Leagues has often led them to be defined as "far-right" (Castelli Gattinara \& Pirro, 2019; Kassimeris \& Jackson, 2015; Richards, 2019). Given the radically nostalgic orientation of the Identitarians and Defence League described above, an equally apt conceptualization of these movements is to describe them as "reactionary." Reactionism is defined by Capelos and Katsanidou (2018) as a political orientation that combines "resentful affectivity with the forceful desire to return to the past" (p. 1272), manifested as opposition to the European Union, cosmopolitanism, and immigration. Reactionism is characterized by sentiments of anger, fear, betrayal, and perceived injustice, along with the aforementioned "radical nostalgia" as noted above (Capelos \& Katsanidou, 2018; Kenny, 2017). The construction of ethnonational symbols derived from the medieval past captures this desire amongst reactionary far-right social movement adherents to give primacy to shared histories, and to mobilize against threats to its re-establishment.

The radically nostalgic and reactionary orientations of the Identitarians and Defence Leagues also has explanatory value for their transnational mobilization. Scholars have recently discussed the Identitarians, Defence League, and other non-party political far-right movements as transnational social movements. The literature on social movements has historically been more often concerned with left-wing movements, but scholars have recently applied this lens to movements on the right, particularly in their mobilization toward paradigmatic change, a disinclination toward primarily electoral politics, and their usage of strategic frames (Blee \& Creasap, 2010; Caiani \& della Porta, 2018; Caiani \& Weisskircher, 2019). Furthermore, scholars have alighted on the increasingly transnational orientation of reactionary far-right social movements (Schlembach, 2011; Zúquete, 2015). This is especially the case in Europe where they are organizing across borders through shared tactics, resources, and strategic frames (Caiani, 2019). Despite having a primarily "national" focus, most far-right organizations are active beyond borders (Caiani, 2018, p. 570). In addition to anti-immigration and anti-Islam movements such as Pegida, Soldiers of Odin, and the formation of the European Counter-Jihad Movement, the Identitarians and European Defence League have been active transnationally for years.

In spite of their aforementioned localized form of nativism, these reactionary far-right social movements acknowledge a civilizational "European" identity, with shared histories and cultural lineages which underpins their organization as transnational movements (Bernsand, 2013). This strategy is both functional and ideational. In the former respect, reactionary movements like the Identitarians and Defence League share aims and tactics, as discussed above. Ideationally, their transnationality recreates a radically nostalgic, medieval, "golden age" whereby distinctive, European nations coalesced in violent, civilizational confrontation with incursionary, Islamic forces (Simpson \& Druxes, 2015, p. 183). The following section argues that this complex "grand narrative" is encapsulated by reactionary far-right social movements through the use of ethnonational symbols appropriated from the medieval period and employed as strategic frames.

\subsection{Reactionary Transnational Social Movements, Ethnonational Symbols, and Strategic Framing}

The Identitarians and Defence Leagues are less concerned with impacting elected politics and more with 
mobilizing adherents around reimagining the world as it once was and how it now ought to be (Busher, 2016, p. 8). Symbolism is integral to their ideal world fabrication as symbols represent "group life," confer membership on adherents as "badges of identity" that demarcate boundaries; they maintain unity and infuse commitment to a common cause (Klatch, 1988). The creation of ethnonational symbols is best discussed through the lens of ethnosymbolism as advanced by Smith (2009). We further argue that ethnonational symbols created by these social movements are constructed through a process referred to as "mediated political medievalism" and that these radically nostalgic ethnonational symbols are ultimately then employed as strategic framing devices.

The ethnosymbolism approach involves analyzing collective identities through symbolic resources made up of traditions, myths, symbols, and other subjective factors (Smith, 2009, p. 16). It firstly argues that repertoires of symbols serve to sharpen distinctions between members and non-members and thusly construct ideational, "us vs. them" boundaries. Secondly, shared memories, traditions, and symbols establish intergenerational continuity and function to establish "grand narratives" nostalgically anchored in an exemplary period or "golden age." Thirdly, symbols are the means by which these collective identities assert a common ethnicity, as well as a transnational common cause which unites distinct nations. Finally, ethnosymbolism advances that the re-appropriation of the ethnic past is important to understanding the creation of ethnonational boundaries in the present (Smith, 2009, p. 39).

This approach suits the analysis of reactionary transnational social movements' creation of ethnonational symbols derived from the medieval period, as through them they operationalize radically nostalgic, newly constructed worlds, establish intergenerational continuity, mobilize members through assertions of ethnic identity, and establish in-group and out-group boundaries. The Identitarians and Defence Leagues construct ethnonational symbols sourced from the medieval period through a process referred to as "medievalism," whereby symbols or narratives originating in the medieval period are used in contemporary contexts (Elliott, 2017, p. 6). This definition creates a dichotomy between myth and reality, with this difference being crucial to our understanding of the adoption of medieval symbolism by social movements as it represents the myth or "gap" where groups alter or simplify the historic time and place for their political purposes in what Elliott refers to as "mediated political medievalism" (Elliott, 2017, p. 10; Livingstone, 2017).

Medievalism functions as the process of converting "symbolic religiosity," which is the consumption of religious symbols for secular purposes, into ethnonational symbols. This is relevant as many of the narratives and symbols appropriated from the medieval period had deeply religious connotations in the period, particularly those from the crusades. Elliott (2017) argues contempo- rary political entrepreneurs, such as the Identitarians and the Defence Leagues, undertake a three-stage medievalism process: Firstly, they select and appropriate medieval objects and symbols, such as a statue of Joan of Arc or the cross of St. George; secondly, through repetition they "flatten" these symbols and insert new meaning laden with their ideology; finally, they couple these symbols with their ethnonationalist ideology. Through medievalism, formerly religious, medieval symbols are transformed into contemporary ethnonational symbols.

Medievalism as a process of secularization is not new. Tyerman (1998, pp. 101, 105) argues that the Protestant Reformation produced a "secularization of the Holy War" and saw the significant losses as a sign of religious impurity. Historiography of the 17th and 18th centuries, such as Maimbourg's History of the Crusades (1675) or Schoeplin's De Scaris Galliae Regum in Orientum Expeditionibus (1726), added to this "secularization" of the crusades because it focused on the heroic actions of individuals, creating national rather than religious usages.

The 19th century witnessed another turn in historiographic focus toward "romantic nostalgia and supremacist ideology" (Tyerman, 1998, p. 117). Examples of this can be seen in William Hillary, an English Knight of Malta, who called for a new crusade in 1840. In the same decade, forgeries of individuals' lineage to crusaders were produced en masse, and in 1895 when a re-enactment of the procession at Clermont marked its 800th anniversary (Tyerman, 1998, pp. 117-118). We can see the idealization of individuals with Frederick Barbarossa as a hero in German propaganda or Keiser Wilhelm II's 1898 visit to Jerusalem and Damascus being portrayed as a pilgrim and holy warrior (Tyerman, 1998, p. 121).

A more recent example from the European farright is the intense mythologizing undertaken by the German Nazi party in the 1920s to 1940s. Nazi identity entrepreneurs liberally appropriated the mythologizing of the medieval period, as seen in the poster of Nazi leader Adolf Hitler appearing as a knight (Figure 1).

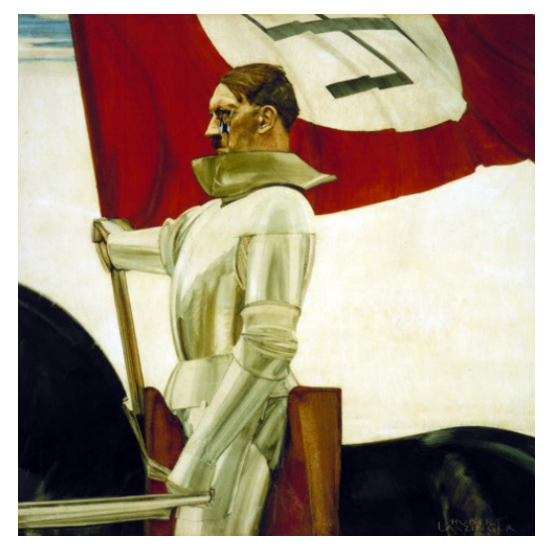

Figure 1. Der Bannerträger (The standard bearer), ca. 1935. Source: The US Holocaust Memorial Museum (n.d.). 
What remains to be elucidated is how ethnonational symbols function as strategic framing devices. Social movement scholars considering far-right mobilization have employed framing as a means of analyzing their transnational strategies. Framing refers to how movement entrepreneurs summarize and simplify complex ideas, grievances, and objectives with a view to aggregating support, compel action and demobilize opponents (Caiani, 2019; Nissen, 2020; see Kiss, 2021, for more on political communication and mobilization). Guenther et al. (2020) consider the use of strategic framing to achieve four ends: to define the problem identified by adherents, to assign causal attribution for the problem, to establish how this problem is morally evaluated and finally, to assign a treatment aimed at solving the problem. As argued in the final section, the Identitarians and Defence Leagues employ ethnonational symbols as convenient strategic framing devices to achieve the above aims, with those drawn from the medieval period common to both movements.

\section{Radical Nostalgia and the Medieval Period: Origins of Reactionary Social Movement Ethnonational Symbols}

The Identitarians and Defence Leagues appropriate narratives and motifs from the medieval period to create unifying ethnonational symbols which establish a radically nostalgic interpretation of Europe's past and idealize a mythologized "golden age" to which their adherents seek a "return." There are many instances of the usage of ethnonational symbols in both movements and while they draw on a wide range of geographical and temporal contexts, the below homes in on the usage of symbols originating from the crusader period. This period is selected because of the ubiquity of these themes in reactionary social movement public content and the demonstrable "us vs. them" dichotomy between European and Islamic powers. Some examples of these themes are a crusader knight in prayer (Figure 2) and a mythologized crusading knight chasing away an observably Muslim mother (Figure 3).

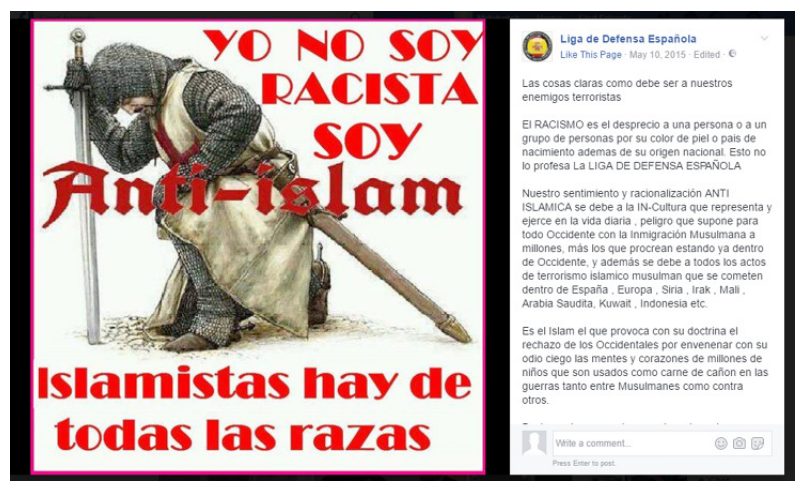

Figure 2. "I am not racist, I am anti-Islam." Source: The Spanish Defence League (2015).

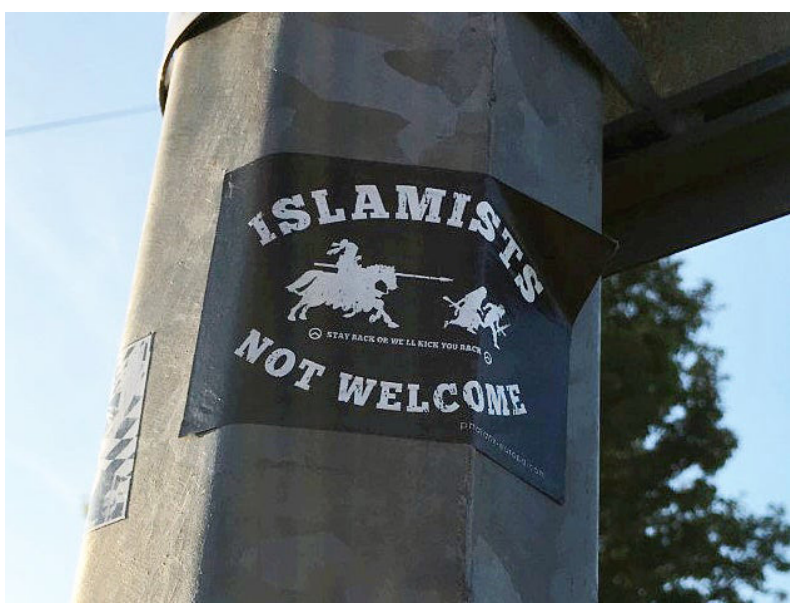

Figure 3. Generation Identity stickers appeared in an Essex town. Source: Sharman and Dearden (2019).

The term "crusades" is used to refer to a series of expeditions to the East beginning in 1095 aimed at regaining the Holy Land from Muslim control. For traditional historians, the crusades ended after the 1291 fall of Acrethe final major Christian stronghold. However, some historians include the Reconquista period in Spain in the late medieval period. Reactionary far-right social movements draw on this period in their ethnonational symbolism (Figure 4).

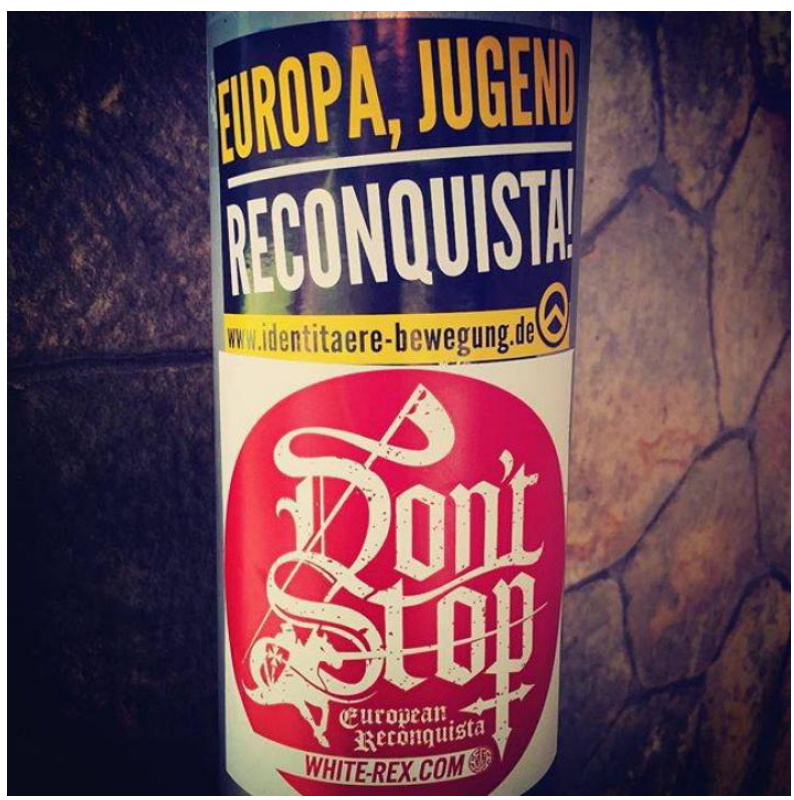

Figure 4. A sticker of the German Identitarian Movement reading "Europe, Youth, Reconquista," alongside a sticker advertising the neo-Nazi martial arts group White Rex. Source: FOIA Research (n.d.).

The First Crusade was launched by Pope Urban II in his sermon at the Council of Clermont (27 November 1095) which called for military support to liberate Christian pilgrimage sites in the Holy Land from Muslim control (Folda, 2008, p. 15). Those who "took up the cross" 
were encouraged by the remission of sins, plenary indulgences, and the hope of ascension to heaven. This was an odd kind of pilgrimage because it was also a war, and therefore, mainly young healthy laymen were encouraged to participate (Riley-Smith, 1987, pp. 6-9). The Identitarians use this event and Pope Urban II's famous words "Deus Vult" (God wills it) as exemplified by Martin Sellner, leader of the Identitäre Bewegung Österreichs (Austria's Identitarian Movement), in his tweet: "To all Christians: Chase away your lousy cardinals and bishops and do something! \#remigration." This tweet was accompanied by an image of Pope Urban II, captioned: “'Defend Europe' and 'Deus Vult,' or God wills it, the rallying cry of the First Crusade" (Zúquete, 2020).

The symbol of the cross linked the two functions of pilgrimage and holy war (Tyerman, 1998, p. 79). As Urban II's speech demonstrates, the cross was associated with the crusades from its beginning and was inscribed with various meanings: a badge of penance, a contractual agreement, fiscal and legal immunities, and a talisman (Tyerman, 1998, pp. 22, 76). The cross most often portrayed on crusader imagery is that of St. George: a red cross on a white background, which became a prolific aesthetic used within crusader imagery from the late medieval period onwards. The predominant organizing symbol of the English Defence League is the cross of St. George as seen online (Figure 5), at demonstrations (Figure 6), and as English Defence League adherents sing patriotic songs like "Keep St. George in My Heart."

St. George's role as a military saint stems from a legend in which he aided Godfrey of Bouillon during the siege of Antioch (21 October 1097-2 June 1098). Dwindling supplies and harsh weather led many crusaders to desert the cause by early 1098 (Riley-Smith, 1987, p. 29). Adhemar of Le Puy, a principal leader in the battle, felt their lack of luck was due to a lack of piety so he ordered his knights to fast for three days, lead a procession, and affix a cross to their garments
(Frankopan, 2016, p. 157). After this, according to legend, an army on horseback led by St. George, St. Demetrius, and St. Mercurius miraculously assisted in defeating the Turks (Riley-Smith, 1987, pp. 30-31). St. George's intervention occurred again at the 1177 Battle of Montgisard (Rogers, 2010, p. 211). These examples demonstrate the connection between piety and war where the favour of God was necessary to achieve victory.

Following a harrowing journey from Europe to the Levant, many viewed the success of the crusade as a miraculous gift from God, stimulating legends and heroic tales, such as St. George's assistance but also the discovery of relics like the Holy Lance and True Cross (Riley-Smith, 1987, p. 85). These relics were carried into battle and served as powerful unifying and galvanizing symbols. For example, while carrying the relic of the True Cross the crusaders went undefeated 31 times until its loss at the 1187 Battle of Hattin (Folda, 2008, p. 18; Murray, 1998, pp. 232-238). By overcoming the odds of a very arduous journey and a number of battles, these relics, as well as the above-mentioned cross of St. George, processions, and other pious acts, became symbols of God's favor. Furthermore, they became the rightful justification of their actions through the will and favor of God, symbolizing within the ideology, the "us vs. them" dichotomy where the Christian crusaders were viewed as the legitimate heirs to the land, saving it from an evil enemy. These concepts were described in, for example, Bernard of Clairvaux's (1090-1153) Liber ad milites templi de laude novæ militiæ (ca. 1120-1136) which demonstrates that the justification of violence undergirded the crusades from the outset. This treatise adheres to arguments put forth by St. Augustine: that although God's commandment states "thou shall not kill," there are exceptions to this rule (Dods, 2014, Book 1, Chapter 21). Bernard uses one of these exceptions, that God commands the death because of injustice done to Him, in order to justify the crusades.

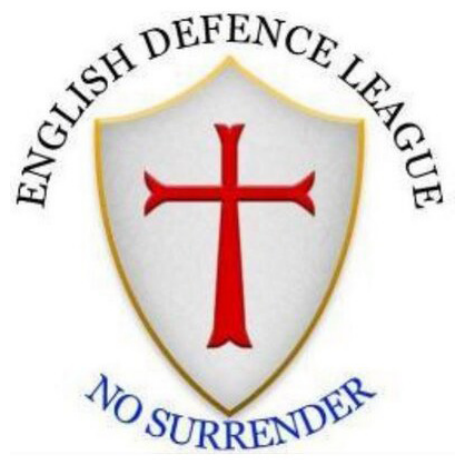

Figure 5. English Defence League Twitter profile photo depicting the crusader cross of St. George, April 11 2021. Source: EDL Huddersfield (n.d.).

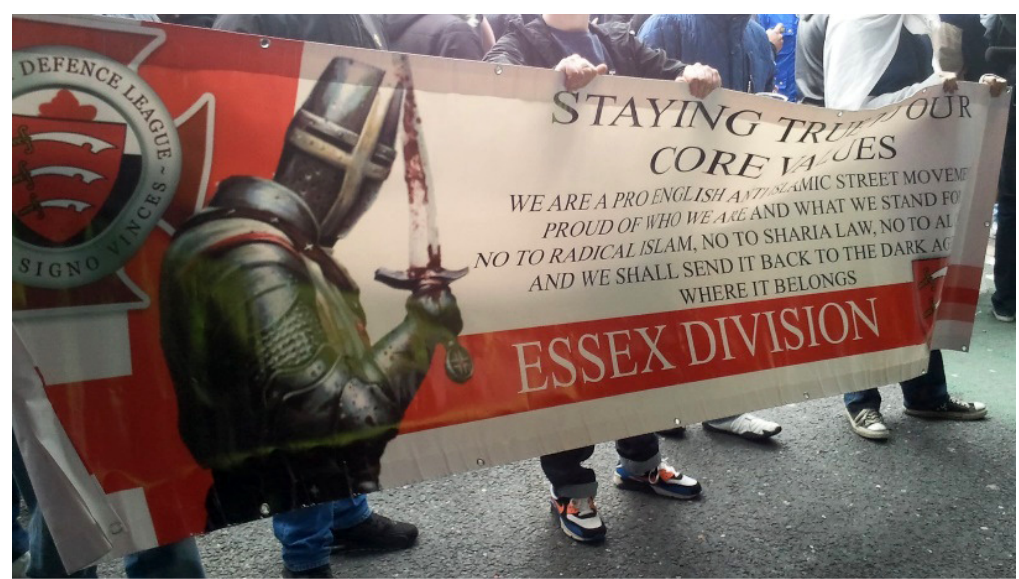

Figure 6. English Defence League Essex Division banner. Source: J. Busher (personal communication). 
Furthermore, according to Bernard, God wills the war because its enemy is evil incarnate, as is seen in his comment that the crusader does not kill man, he kills evil: "not homicide...but malicide" (Leclercq \& Rochais, 1963, Chapter 4; see also Gazzoli, 2015). This distinction of casting Muslims into the category of evil and distinguishing between homicide and malicide justifies their killing and sets up an "us vs. them" dichotomy. Rather than advocate violence outright, the Identitarians and Defence Leagues, through the adoption of ethnonational symbols, draw on the crusades as both advocating the use of violence and legitimizing its usage.

One common reference is that of the crusading English King Richard the Lionheart who was one of the crusader knights to place himself under the protection of St. George. Richard I played a key role in the Siege of Acre (August 1189-July 1191), which was described as "the great set-piece of the Third Crusade" (McGlynn, 2018). Acre was important strategically because it was a port city. The siege went on for months and casualties were severe for both sides (Lock, 2006, p. 151). Philip II and Richard I offered their support in April and June 1191 and by July, Richard I accepted the city's second proposal of surrender which included money, ships, stores, a prisoner exchange, and the return of the True Cross relic (Lock, 2006, p. 154). Saladin failed to deliver some prisoners of rank and Richard I retaliated by ordering the massacre of approximately 3000 Muslim hostages including wives and children (Lock, 2006, p. 77; Riley-Smith, 1987, p. 116).

During the crusades, a number of military orders were formed or expanded to ensure the safe passage of pilgrims, like the Knights Templar, a group formed in 1119 by Hugh de Payens, Godfrey de Saint Omer, and other knights. The templar knights, in their white mantles with the symbol of St. George's Cross on them, policed pilgrimage routes and managed robust economic infras- tructure throughout Christendom until Pope Clement V disbanded the order in 1312.

Highly romanticized in literature, film, and television, the Knights Templar feature prominently in reactionary social movement imagery and narratives. With close connections to the English Defence League and Britain First, Knights Templar International was founded in 2015 by long-time far-right activist Jim Dowson (Figure 7; Cox \& Meisel, 2018). Aimed at allowing far-right sympathizers to support anti-Islam, anti-immigrant, and anti-liberal globalist efforts, it is believed to have thousands of paying members globally (Cox \& Meisel, 2018).

Images and historic narratives from the crusades have been selectively employed by reactionary social movements in Europe. Additionally, these movements have drawn on prominent individuals as well as battles against Muslim commanders from the Early and Late medieval periods, where symbolic narratives are also appropriated. Prominent references include the figure of Charles Martel, who defeated Muslim Umayyad forces led by Abdul Rahman Al Ghafiqi at the 732 Battle of Tours and battles between European kingdoms and the Ottoman Empire in the Late Middle Ages, such as the 1543 Siege of Nice (Braouezec, 2016; Richards, 2019; Zúquete, 2018).

It is outside this inquiry's scope to address the many inaccuracies and simplifications by reactionary movements utilizing these ethnonational symbols, such as the well-documented esteem between Richard I and his Muslim rival Saladin, or the fact that the Ottomans were in alliance with France at the Siege of Nice. What is evident by these selections is the preference for events and narratives where Europeans, primarily Christians, are in violent confrontation with Eastern forces which are predominately Muslim. The final section discusses why these historic motifs and narratives are appropriated by reactionary social movements as ethnonational symbols.

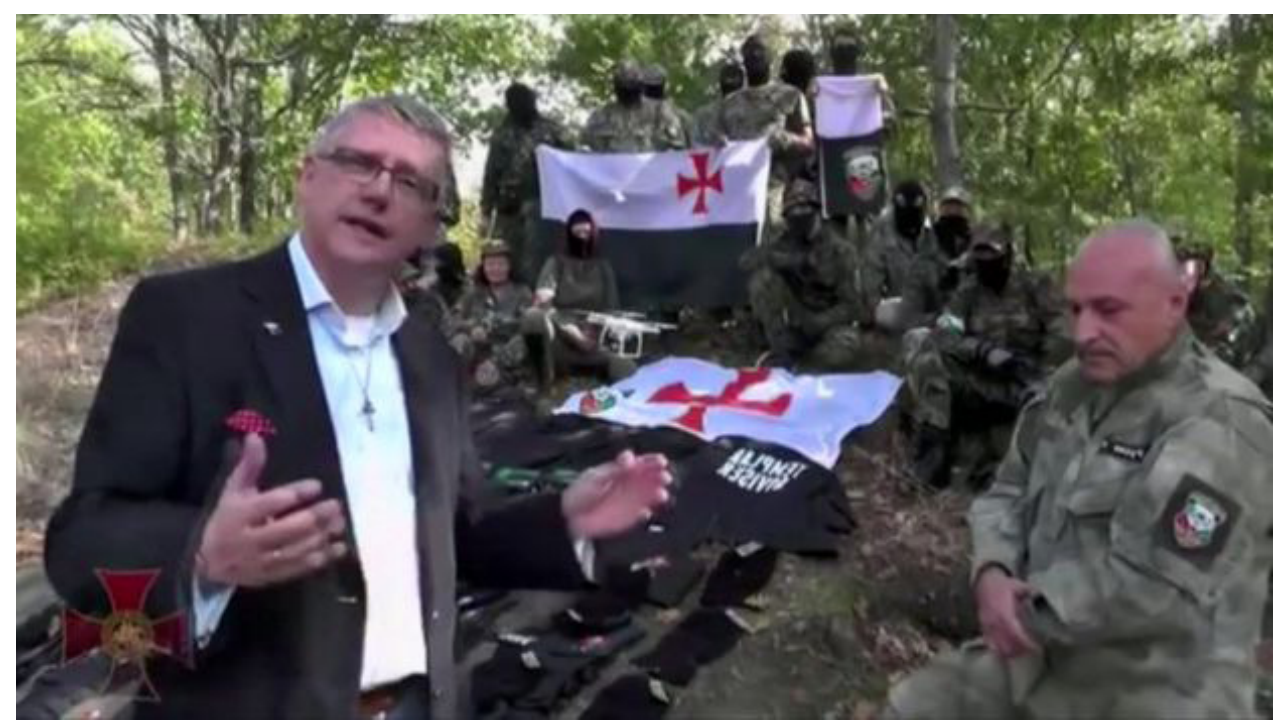

Figure 7. Jim Dowson has spoken in videos of an impending clash between Christians and Muslims, 1 May 2018. Source: Cox and Meisel (2018). 


\section{The Medieval Reimagined: The Utility of Ethnonational Symbols for Reactionary Social Movements}

The Identitarians and Defence Leagues are reactionary transnational social movements which have adopted ethnonational symbols derived from radically nostalgic interpretations of the medieval world, which encapsulates and simplifies strategic framing objectives: firstly, through recalling a "golden age" of distinct, ethnonational European identities, which in their view has now been lost; secondly, by identifying multiculturalism, immigration, and the concomitant Islamization of Europe as the explanation for the erosion of this ideal world; thirdly, ethnonational symbols create a moral framework arguing that the transnational battle against Islam in the medieval period continues contemporaneously, but is now ethnonational rather than religious; and finally, that these forces should be expelled from Europe and that violence is a justifiable response to achieve these aims. The below considers each of these strategic frames in turn.

Firstly, the use of ethnonational symbols derived from the medieval period stems from a radically nostalgic interpretation of the medieval period. Reactionary social movements believe that distinct nations existed in their purest form during this period and mobilize to "reinforce" the ethnonational cultures specific to their territorialized nations. For instance, Génération Identitaire draws on distinctly French associations, such as the late medieval Military Commander Joan of Arc and the early medieval King Charles Martel (Elliott, 2017, p. 1; Simpson \& Druxes, 2015, p. 177). In parallel, the English Defence League recalls the mythology of the crusades through figures such as Richard I and the myths of St. George. These ethnonational symbols nostalgically recall "golden ages" for these particular national identifications and are representative statements of belonging, as they construct national myths believed to uniquely define these nations. They are also inherently exclusionary, ensuring only those who claim derivation from these nations are admitted to membership.

Secondly, ethnonational symbols apportion causal blame to the sources of the perceived loss of this "golden age" and the erosion of ethnonational attachments: multiculturalism and the immigration of Muslims. The ideology of the Identitarians and Defence Leagues advances that multiculturalism is leading to an erosion of ethnonational cultures. For instance, rather than accept the European Union's construction of a continent-wide civic nationalism, reactionary transnational social movements are crafting a counter transnational identity based on pre-modern notions of distinct nations united by an overarching Christian identity. For adherents, the crusades are a period which embodies this continent-wide identity and offers a compelling foil and alternative world through which to oppose civic nationalism. This ethnonational European civilization is exclusionary, such that immigrants, especially Muslim immigrants, are not able to become members.

Furthermore, the Identitarians and Defence Leagues adhere to a paranoid belief that an imperialistic Islam is attempting to conquer Europe through immigration and conversion. Despite the temporal and geographic variation in the recollection of medieval myths by adherents, one nearly universal narrative is evident, that of a predominantly united Christian Europe in a violent, existential battle against Islam. Key battles, discussed above, are recalled to delineate the boundaries of this "us vs. them" civilizational struggle. They are also employed to indicate intergenerational inheritance, whereby the mobilization of contemporary ethnonationalists view themselves as inheritors of an ongoing battle against Islam in Europe. Finally, references to these dramatic battles framed as existential to European Christian civilization also convey a sense of urgency, indicating that without immediate violent resistance to defend Europe, both the wider European civilization as well as distinct ethnonations will be destroyed.

Thirdly, the construction of ethnonational symbols derived from radically nostalgic interpretations of the medieval period moralizes the objectives of reactionary social movements. The crusades were conceived as a "moral" struggle, where distinct ethnic nations were mobilized together as Christians in common cause against a perceived threat from Islam. As noted above, Christian symbols were employed by crusader leaders to encapsulate moral justification. Symbols were imbued with intense religious meaning and as primary indications of allegiance. Through the process of mediated political medievalism, reactionary transnational movements have converted these religious symbols into unifying ethnonational symbols. This moral framework allows for their transnational, "European" movements to retain nativist attachments, but which are nevertheless united transnationally.

Finally, ethnonational symbols derived from the medieval period prescribe and justify a violent approach to returning to the idealized world envisioned by reactionary social movements. A hallmark of these movements is their effort to obfuscate their political ideology to render their movements and their views more palatable to individuals outside extremism (Guenther et al., 2020). Despite purporting to be non-violent, the Identitarians and Defence Leagues undertake militarystyle training and expect to engage in violent confrontation during demonstrations. Rather than call for violence directly, they use ethnonational symbols from the crusades to legitimize violence.

\section{Conclusion}

Alongside the rise of reactionary political parties in Europe in the first two decades of the 2000s, reactionary transnational social movements have also emerged and prominent amongst them are the Defence Leagues 
and the Identitarians. These movements emphasize nativist, local attachments but have united transnationally around opposition to multiculturalism, immigration, and Islam. Espousing ethnonational philosophies, they have reimagined a radically nostalgic mythologized "golden age" of distinct nations, they advocate an end to immigration, and oppose the perceived Islamization of Europe.

Medieval symbols drawn from the crusades reference heroic figures such as St. George, Richard I, and the Knights Templar, as well as key battles such as the Siege of Antioch and the Siege of Acre. Once principally Christian symbols imbued with religiosity, these themes have been reconstructed through mediated political medievalism and are now employed as ethnonational symbols by the Identitarians and the Defence Leagues. Ethnonational symbols encapsulate the philosophies and political objectives of the Identitarians and the Defence Leagues in a manner that obfuscates their xenophobic, violent intentions.

The construction of ethnonational symbols derived from the medieval period reimagines ideal worlds through delineating an "us vs. them" boundary between members of distinct "European" nations and non-members, recalls and simultaneously establishes an intergenerational, transnational struggle against the perceived incursion of Islam, and advances a solution to the erosion of ethnonational identities by expelling, including through violence, Muslims from Europe.

This article's limitations have left open a number of possible avenues for further research. Firstly, a more thorough consideration of political economy factors in driving mobilization is needed. As touched on by Caiani (2019) and Muis and Immerzeel (2017), these grievances have become more consequential since the 2009 economic crisis. Additional research emphasizing economic grievances may better elucidate the antisemitic nature of these movements in Europe, where literature on the subject in the US is more advanced (Blee \& Creasap, 2010). Secondly, further theorizing is required to explicate on the multi-layered attachments within far-right reactionary movements, which variously espouse forms of nativist attachments to the ethnonation, a transnational "European" nativism (including beyond the European continent), and attachments to specific localities. Finally, exploration of the other historical contexts recalled by far-right adherents is required, including the use of ethnonational symbols derived from the early and late medieval period emphasizing other Christian-Islamic encounters, such as battles between the Ottoman Empire and European forces.

\section{Acknowledgments}

We would like to thank the editorial team of this thematic issue Tereza Capelos, Mikko Salmela, Stavroula Chrona, and Cristiano Bee, as well as Dr. James Doherty and lain Dyson.

\section{Conflict of Interests}

The authors declare no conflict of interests.

\section{References}

Bernsand, N. (2013). Friend or foe? Contemporary debates on Islam and Muslim immigrants among Swedish Identitarians. In T. Hoffmann \& G. Larsson (Eds.), Muslims and the new information and communication technologies: Notes from an emerging and infinite field (pp. 163-189). Springer.

Blee, K. M., \& Creasap, K. A. (2010). Conservative and right-wing movements. Annual Review of Sociology, 36(1), 269-289.

Braouezec, K. (2016). Identifying common patterns of discourse and strategy among the new extremist movements in Europe: The case of the English Defence League and the Bloc Identitaire. Journal of Intercultural Studies, 37(6), 637-648.

Busher, J. (2016). The making of anti-Muslim protest (1st ed.). Routledge.

Caiani, M. (2018). Radical right cross-national links and international cooperation. In J. Rydgren (Ed.), The Oxford handbook of the radical right (pp. 562-585). Oxford University Press.

Caiani, M. (2019). The rise and endurance of radical right movements. Current Sociology, 67, 1-18.

Caiani, M., \& della Porta, D. (2018). The radical right as social movement organizations. In J. Rydgren (Ed.), The Oxford handbook of the radical right (pp. 327-347). Oxford University Press.

Caiani, M., \& Weisskircher, M. (2019). How many "Europes"? Left-wing and right-wing social movements and their visions of Europe. In C. Flesher Fominaya \& R. A. Feenstra (Eds.), Routledge handbook of contemporary European social movements: Protest in turbulent times (pp. 30-45). Routledge.

Capelos, T., \& Katsanidou, A. (2018). Reactionary politics: Explaining the psychological roots of anti preferences in European integration and immigration debates. Political Psychology, 39(6), 1271-1288.

Castelli Gattinara, P., \& Froio, C. (2014). Discourse and practice of violence in the Italian extreme right: Frames, symbols, and identity-building in CasaPound Italia. International Journal of Conflict and Violence, 8, 154-170.

Castelli Gattinara, P., \& Pirro, A. L. P. (2019). The far right as social movement. European Societies, 21(4), 447-462.

Conversi, D. (2009). Globalization and nationalism in Europe: Demolishing walls and building boundaries. In I. P. Karolewski \& A. M. Suszycki (Eds.), Multiplicity of nationalism in contemporary Europe (pp. 81-106). Lexington Books.

Cox, A., \& Meisel, S. (2018, May 1). Is this Britain's most influential far-right activist? $B B C$. https://www.bbc. com/news/uk-43924702 
Dods, M. (2014). The works of Aurelius Augustine, bishop of Hippo (Vol. 1: The city of God). T\&T Clark.

Durie, A. (2019, January 19). At the heart of hate: Inside France's Identitarian movement. Are We Europe Magazine. https://magazine.areweeurope. com/stories/uprooted/generation-identitaire

Eatwell, R., \& Goodwin, M. (Eds.). (2010). The new extremism in 21st century Britain. Routledge.

Ebner, J. (2019, April 4). Who are Europe's far-right Identitarians? Politico. https://www.politico.eu/article/ who-are-europe-far-right-identitarians-austriageneration-identity-martin-sellner

EDL Huddersfield. [@EDLHuddersfield]. (n.d.). Tweets [Twitter profile]. https://twitter.com/edlhuddersfield

Elliott, A. B. R. (2017). Medievalism, politics and mass media: Appropriating the Middle Ages in the twentyfirst century. Boydell Press.

FOIA Research. (n.d.). Europa Jugend Reconquista White Rex.jpg. https://www.foiaresearch.net/media/ image/europa-jugend-reconquista-white-rexjpg

Folda, J. (2008). Crusader art: The art of the crusaders in the holy land: 1099-1291. Lund Humphries.

Ford, R. (2010). Who might vote for the BNP? Survey evidence on the electoral potential of the extreme right in Britain. In R. Eatwell \& M. Goodwin (Eds.), The new extremism in 21st century Britain (pp. 145-169). Routledge.

Frankopan, P. (2016). The First Crusade: The call from the east. Harvard University Press.

Gazzoli, M. J. (2015, March 17). St. Bernard and the theology of crusade. The Josias. https://thejosias. com/2015/03/17/st-bernard-and-the-theology-ofcrusade

Grindheim, J. E. (2019). Why right-leaning populism has grown in the most advanced liberal democracies of Europe. The Political Quarterly, 90(4), 757-771.

Guenther, L., Ruhrmann, G., Bischoff, J., Penzel, T., \& Weber, A. (2020). Strategic framing and social media engagement: Analyzing memes posted by the German Identitarian Movement on Facebook. Social Media + Society, 6(1), 1-13.

Hope Not Hate. (n.d.). Defence League network. https://www.hopenothate.org.uk/research/ islamophobia-hub/profiles/anti-muslim-streetprotest-movements/defence-league-network

Jackson, P., \& Feldman, M. (2011). The EDL: Britain's "new far right" social movement. University of Northampton. http://nectar.northampton.ac.uk/ 6015

Karolewski, I. P. (2009). European nationalism and European identity. In I. P. Karolewski \& A. M. Suszycki (Eds.), Multiplicity of nationalism in contemporary Europe (pp. 59-80). Lexington Books.

Kassimeris, G., \& Jackson, L. (2015). The ideology and discourse of the English Defence League: "Not racist, not violent, just no longer silent." The British Journal of Politics \& International Relations, 17(1), 171-188.

Kaufmann, E. (2019). Can narratives of white identity reduce opposition to immigration and support for hard Brexit? A survey experiment. Political Studies, 67(1), 31-46.

Kaya, A. (2021). Islamist and nativist reactionary radicalization in Europe. Politics and Governance, 9(3), 204-214.

Kenny, M. (2017). Back to the populist future? Understanding nostalgia in contemporary ideological discourse. Journal of Political Ideologies, 22(3), 256-273.

Kiss, B. (2021). Double ressentiment. The political communication of Kulturkampf in Hungary. Politics and Governance, 9(3), 227-236.

Klatch, R. E. (1988). Of meanings \& masters: Political symbolism \& symbolic action. Polity, 21(1), 137-154.

Koch, A. (2017). The new crusaders: Contemporary extreme right symbolism and rhetoric. Perspectives on Terrorism, 11(5), 13-24.

Kuzio, T. (2009). Civic nationalism and the nation-state: Towards a dynamic model of convergence. In I. P. Karolewski \& A. M. Suszycki (Eds.), Multiplicity of nationalism in contemporary Europe (pp. 9-31). Lexington Books.

Leclercq, J., \& Rochais, H. (Eds.). (1963). Sancti Bernardi opera (Vol. 3: Tractatus et opuscula). Editiones Cistercienses.

Livingstone, J. (2017, August 15). Racism, medievalism, and the white supremacists of Charlottesville. The New Republic. https://newrepublic.com/article/ 144320/racism-medievalism-white-supremacistscharlottesville

Lock, P. (2006). The Routledge companion to the crusades. Routledge.

Maly, I. (2018). The new right, global nationalistic activism and the Flemish Identitarian movement Schild \& Vrienden: A case study. Social Media + Society. https://research.tilburguniversity.edu/en/ publications/the-new-right-global-nationalisticactivism-and-the-flemish-ident

Mattheis, A., \& Winter, C. (2019). The greatness of her position: Comparing Identitarian and jihadi discourses on women. ICSR.

McGlynn, S. (2018, May 2018). The siege of Acre: A monstrous blot on the Third Crusade. The Spectator. https://www.spectator.co.uk/2018/05/the-siegeof-acre-a-monstrous-blot-on-the-third-crusade

Meleagrou-Hitchens, A., \& Brun, H. (2013). A neonationalist network: The English Defence League and Europe's counter-jihad movement. The International Centre for the Study of Radicalisation and Political Violence. http://icsr.info/wp-content/uploads/ 2013/03/ICSR-ECJM-Report_Online.pdf

Morrow, E. A., \& Meadowcroft, J. (2019). The rise and fall of the English Defence League: Self-governance, marginal members and the far right. Political Studies, 67(3), 539-556.

Mudde, C. (2007). Populist radical right parties in Europe. Cambridge University Press. 
Muis, J., \& Immerzeel, T. (2017). Causes and consequences of the rise of populist radical right parties and movements in Europe. Current Sociology, 65(6), 909-930.

Murray, A. V. (1998). Mighty against the enemies of Christ: The relic of the true cross in the armies of the kingdom of Jerusalem. In J. France \& W. G. Zajac (Eds.), The crusades and their sources: Essays presented to Bernard Hamilton (pp. 217-238). Ashgate.

Nissen, A. (2020). The trans-European mobilization of "Generation Identity." In O. C. Norocel, A. Hellström, \& M. B. Jørgensen (Eds.), Nostalgia and hope: Intersections between politics of culture, welfare, and migration in Europe (pp. 85-100). Springer.

Olsson, A. M. (2009). Theorizing regional minority nationalism. In I. P. Karolewski \& A. M. Suszycki (Eds.), Multiplicity of nationalism in contemporary Europe (pp. 107-132). Lexington Books.

Pilkington, H. (2016). Loud and proud: Passion and politics in the English Defence League. Manchester University Press.

Richards, I. (2019). A philosophical and historical analysis of "Generation Identity": Fascism, online media, and the European new right. Terrorism and Political Violence. Advance online publication. https://doi.org/ 10.1080/09546553.2019.1662403

Riley-Smith, J. (1987). The crusaders: A short history. Athlone Press.

Rogers, C. J. (2010). The Oxford encyclopaedia of medieval warfare and military technology. Oxford University Press.

Rooduijn, M. (2015). The rise of the populist radical right in Western Europe. European View, 14(1), 3-11.

Schlembach, R. (2011). The transnationality of European nationalist movements. Revue Belge de Philologie et d'Histoire, 89(3/4), 1331-1349.
Sharman, J., \& Dearden, L. (2019, May 21). "Anti-Islamic" posters in Essex showing crusader chasing woman in burqa with AK-47 investigated by police. Independent. https://www.independent.co.uk/news/uk/ crime/islamist-stickers-essex-not-welcomegeneration-identity-rayleigh-police-a8923166.html

Simpson, P. A., \& Druxes, H. (2015). Digital media strategies of the far right in Europe and the United States. Lexington Books.

Smith, A. D. (2009). Ethno-symbolism and nationalism: A cultural approach. Routledge.

The Spanish Defence League. (2015, May 10). Las cosas claras como debe ser a nuestros enemigos terroristas [Let us be perfectly clear so our enemies, who are terrorists, understand] [Facebook status webpage]. https://www.facebook.com/LigadeDefensa/photos/ a.193934667287716.53961.189960594351790/ 1061503757197465

The US Holocaust Memorial Museum. (n.d.). Der Bannerträger (The standard bearer), by Hubert Lanzinger, circa 1935. https://www.ushmm.org/ propaganda/archive/painting-the-standard-bearer

Tyerman, C. (1998). The invention of the crusades. Macmillan Press.

Wodak, R. (2015). The politics of fear: What right-wing populist discourses mean. SAGE.

Zúquete, J. P. (2015). The new frontlines of right-wing nationalism. Journal of Political Ideologies, 20(1), 69-85.

Zúquete, J. P. (2018). The Identitarians: The movement against globalism and Islam in Europe. University of Notre Dame Press.

Zúquete, J. P. (2020, August 7). The European Alt-Right's crusade against Pope Francis. Church Life Journal. https://churchlifejournal.nd.edu/articles/theeuropean-alt-rights-crusade-against-pope-francis

\section{About the Authors}

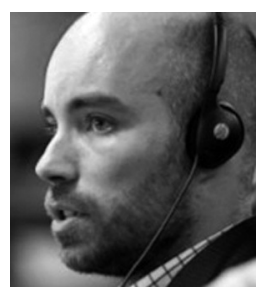

Matthew Godwin holds a PhD from University College London and has published articles in the Canadian Foreign Policy Journal, the Journal of Ethnic and Migration Studies, Globalizations, and a number of other publications. He is currently a program lead in the Extremism Policy Unit of the Tony Blair Institute for Global Change.

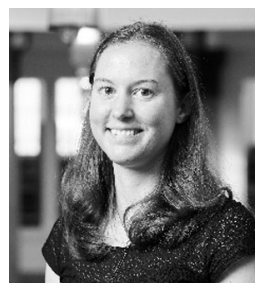

Elisabeth Trischler is a PhD candidate in the Institute for Medieval Studies, exploring the intersection of medieval art history and literature. Her current project analyzes how architecture and urban expansion in 13th- and 14th-century Florence influenced the poetry of Dante Alighieri's Commedia. She also investigates how medieval culture has been reproduced and transmitted in contemporary culture. 